\title{
The Development of In Vitro Culture Sterilization Method of Gametophyte Explant Lopholejeunea sp.
}

\author{
Anna Widyastuti, Afiatry Putrika, Astari Dwiranti, Andi Salamah, Niarsi Merry Hemelda, Windri Handayani* \\ Department of Biology, Faculty of Mathematical and Natural Sciences, Universitas Indonesia, Depok, Indonesia
}

ARTICLE INFO

Article history:

Received October 13, 2020

Received in revised form February 15, 2021

Accepted March 1, 2021

\section{KEYWORDS:}

contamination,

gametophyte,

in vitro culture,

Lopholejeunea sp.,

sterilization

\begin{abstract}
In vitro cultures of leafy liverworts are still facing significant challenges due to highlevel of explant contamination. The sterilization process can easily damage the structure of liverwort after exposure to the disinfectant. This study was to determine the concentration and time exposure of commercial bleach as a disinfectant to suppress contamination using the gametophyte culture of Lopholejeunea sp. The experiment consisted of control and six treatment combinations of commercial bleach with concentration $0.5,0.75$, and $1 \%(v / v)$, and exposure time (60 and 90 seconds). The type and location of contamination, the color of the explants after sterilization, and response after 30 days were observed. The results showed that the $0.75 \%$ bleach with 60 and 90 seconds exposure time had a lower contamination until the 7 th day of culture. The most common type of contamination is bacteria and fungi that arise from the explant. Despite the contamination, it did not inhibit shoot formation. Further studies still needed to determine the type of fungicides and antibiotics with the most potent concentration and exposure time should be tested to obtain an axenic and viable culture of liverworts Lopholejeunea sp.
\end{abstract}

\section{Introduction}

Liverworts have several ecological and biochemical usage. In nature, liverworts can act as pioneer plants in the succession process (Bahuguna et al. 2013), a micro habitat for microorganisms, prevent erosion and increase the capacity of storing groundwater (LaRoe 1995; Abdullah et al. 2019), absorbent for carbon sink and nutrients, indicator of air pollution, and indicators of climate change (Konrat et al. 2008; Tuba et al. 2011). Meanwhile, in terms of biochemistry, the mosses store bioactive compounds of terpenoids and flavonoids in a typical organelle called the oil body (Gradstein et al. 1988). These compounds have the potential to be used as antibacterial, antifungal, and anti-insects (Asakawa 2012; He et al. 2013). Lopholejeunea is one of leafy liverworts genera belonging to the family Lejeuneaceae and subfamily Ptychanthoidae (Zhu and Gradstein 2005; ITIS 2008). It has a blackish-green colony and covers most of the substrate(Figure1).AccordingtoGradsteinetal.(1988), Lopholejeunea contain abundance of sesquiterpenes and flavonoids, which have the potential to be used in

\footnotetext{
* Corresponding Author

E-mail Address: windri.h@sci.ui.ac.id

many applications as for antibacterial, antinematode, and antifungal (Asakawa 2012; He et al. 2013).

Meanwhile, studies related to its potential, morphology, physiology, and molecular are still little concern compared to higher plants (Sabovljevic et al. 2014) because of the limited amount of biomass in nature. Therefore, its pure biomass should be propagated to improve the studies for their taxonomy characteristics and biochemical compounds from this species (He et al. 2013). In vitro culture can be an alternative method, used to propagate liverworts. The parts from the sample that can be the source for in vitro culture explant were the gametophyte or sporophyte parts can be culture to a medium under sterile conditions (Vujicic et al. 2010). Several studies on the in vitro culture of mosses (Allsopp 1957; Beike et al. 2010; Pandey et al. 2014) and liverworts (Silvae-Costa et al. 2016) tend of using sporophytes part as initial explants. However, the use of the sporophyte phase in liverworts has a short period in its life cycle, so it cannot be observed easily at a time. Therefore, the gametophyte phase can be an alternative for in vitro culture explants (Crandall-stotler et al. 2008; Glime 2017).

Gametophyte in vitro culture of liverwort should be disinfected first before planting in a culture condition 


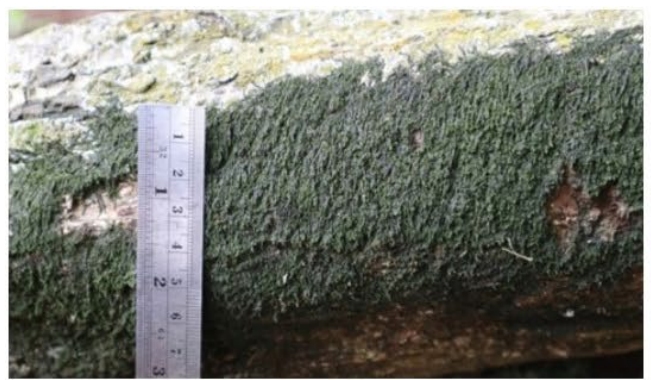

a

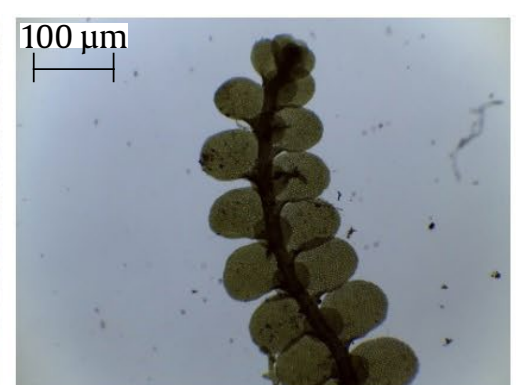

b

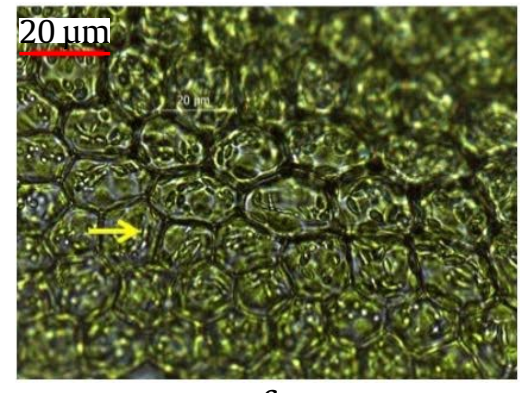

C

Figure 1. Lopholejeunea characteristics (a, b), Morphology (c), oil body of Lopholejeunea sp. microscopically

(Sabovljevic et al. 2014). The common disinfectant used for explant sterilization is sodium hypochlorite (Duckett et al. 2004; Carey et al. 2015). It has been used in some research to sterilize mosses (Pandey et al. 2014) and liverwort explants (Beike et al. 2010). However, a high concentration of disinfectant will kill the explant cells. Meanwhile, a low concentration of disinfectants tends to not strong enough to remove the contaminants (Duckett et al. 2004). The gametophyte phase of leafy liverworts consists of one layer of tissue, that is not protected by the cuticle so that the tissue tends to be fragile and easily to shattered after being exposed to disinfectants (Sabovljevic et al. 2009). Moreover, leafy liverworts can become a habitat for microorganisms and other invertebrates (Makinde et al. 2014), making it challenging to obtain sterile cultures (Vujicic et al. 2010). This research was conducted to determine the concentration of bleaching agent for disinfectants which can suppress contamination with high explant viability in the gametophyte culture of liverwort Lopholejeunea sp.

\section{Materials and Methods}

\subsection{Plant Sources and Materials Preparation}

The liverwort of this experiment obtains from the surface of the root of the Ketapang tree (Terminalia catappa) found at the Faculty of Mathematics and Natural Sciences UI, Depok. This research was conducted at the Department of Biology FMIPA UI from January to June 2019. The medium used was $1 / 2$ MS (Murashige-Skoog). The sterilizing agents used were distilled water, commercial bleaching with the active ingredient sodium hypochlorite (Bayclin) $0.5 \%, 0.75 \%, 1.0 \%$, and Tetracycline $2.5 \mathrm{mg} / \mathrm{ml}$. The color standard used for explants color observation is the Ace Paint color card. The microscope used for contaminant observation was Leica M500 light microscope.

\subsection{Explant Sterilization}

The explants parts used in this research were the apical tips of gametophyte. We used apical tips with length $2-4 \mathrm{~mm}$. The explant sterilization process consists of two stages, which are sterilization inside the laminar air flow cabinet (LAFC) and outside the LAFC. Sterilization outside LAFC carried out by washing the apical tips of gametophyte two times for 10 minutes under running water to remove the dirt. After that, the explant sterilization process continued inside the LAFC.

Explant sterilization inside the LAFC consists of eight stages done by following an aseptic method. First, apical tips were placed in a sterile tube using sterile tweezers. After that, $10 \mathrm{ml}$ of sterile distilled water was put into the container and shaken for 1 minute. Furthermore, the explants were divided into groups according to each "Bayclin" concentration (0.5\%, $0.75 \%$, and $1.0 \%$ ) (Table 1). Apical tips gametophyte explants that had been rinsed with sterile distilled water immersed in $10 \mathrm{ml}$ "Bayclin" solution. The exposure time of each explant soaked in "Bayclin" solution was carried out according to the treatment of exposure time, which is 60 and 90 seconds while shaken the tube occasionally so that the explant will be exposed to the sterilizer. After that, apical tips from gametophyte washed into sterile distilled water for three times. Next, the apical tips from gametophyte part were soaked in $10 \mathrm{ml}$ of $2.5 \mathrm{mg} / \mathrm{ml}$ Tetracycline solution, and shaken for 1 minute. Then, the solution was discarded, and the apical tips rinsed three times with sterile distilled water. The explants were then planted in $1 / 2$ MS medium in bottle culture. Each bottle culture planted with three apical tips.

\subsection{Culture Environment and Observation}

The culture was incubated and checked every week for bacterial, algal, and fungal contamination. The culture was maintenance at a temperature of 
Table 1. Treatment codes for concentration and duration of "Bayclin" exposure of Lopholejeunea sp. gametophyte explants

\begin{tabular}{|c|c|}
\hline Treatment code & Sterilant \\
\hline $\mathrm{K}$ & Tetracycline $2.5 \mathrm{mg} / \mathrm{ml}$ (1 minute) \\
\hline AY & "Bayclin" $0.5 \%$ (60 seconds) + \\
\hline & Tetracycline $2.5 \mathrm{mg} / \mathrm{ml}$ (1 minute) \\
\hline $\mathrm{AZ}$ & "Bayclin" 0.5\% (90 seconds) + \\
\hline & Tetracycline $2.5 \mathrm{mg} / \mathrm{ml}$ (1 minute) \\
\hline BY & $\begin{array}{l}\text { "Bayclin" } 0.75 \% \text { (60 seconds) + } \\
\text { Tetracycline } 2.5 \mathrm{mg} / \mathrm{ml} \text { ( } 1 \text { minute) }\end{array}$ \\
\hline $\mathrm{BZ}$ & $\begin{array}{l}\text { "Bayclin" } 0.75 \% \text { (90 seconds) + } \\
\text { Tetracycline } 2.5 \mathrm{mg} / \mathrm{ml} \text { ( } 1 \text { minute) }\end{array}$ \\
\hline CY & "Bayclin" $1 \%$ (60 seconds) + \\
\hline & Tetracycline $2.5 \mathrm{mg} / \mathrm{ml}$ (1 minute) \\
\hline $\mathrm{CZ}$ & $\begin{array}{l}\text { "Bayclin" } 1 \% \text { (90 seconds) + } \\
\text { Tetracycline } 2.5 \mathrm{mg} / \mathrm{ml} \text { (1 minute) }\end{array}$ \\
\hline
\end{tabular}

$21 \pm 2{ }^{\circ} \mathrm{C}$ with humidity in the range of $30-60 \%$. The light sources supplied by cool-white fluorescent tubes with a periodicity of 16 hours light 8 hours dark and the light intensity 2000 lux.

The qualitative parameters were the type of contaminant that appeared, the location of the contamination, and the explant color. Quantitative parameters were the percentage of contamination, explant growth based on the percentage of growth, and the number of branches. Observations were done after 3 days (D3), 7 days (D7), 14 days (D14), and 21 days (D21) days after planted on to the medium respectively.

Data were arranged based on qualitative and quantitative parameters of the explant from sterilization. The percentage of contamination and explant growth data is processed using Microsoft Excel. Data explants color, type of contaminant, and location of contamination are discussed descriptively.

\section{Results}

\subsection{Explants Color After Sterilization Process}

The color of liverworts gametophyte explant had changed after exposed to disinfectant from blackish green (honeysuckle vine) to yellowish-green (Figure 2 ). The explants tend to turn to yellow after expose to higher concentration and longer duration of Bayclin (Table 2). The color of explants that the least changed was the treatment of Bayclin $0.5 \%$ for 60 and 90 seconds. Meanwhile, explants with Bayclin $1 \%$ treatment for 60 and 90 seconds had a very discolored explant color. Based on the data in Table 2 , on day 21, all treatments have burnished gold or dark brown color.

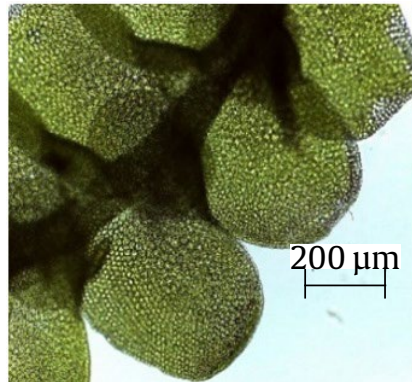

a b

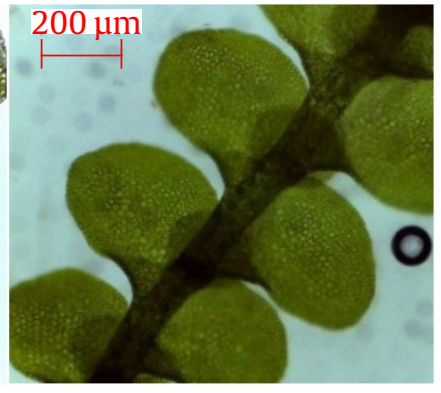

Figure 2. The explants of Lopholejeunea sp. color changed (a), before (b), after exposed to disinfectants on 21 day of culture

\subsection{Contamination and Type of Contaminant}

The addition of "Bayclin" of $0.5 \%, 0.75 \%$, and $1.0 \%$ with Tetracycline $2.5 \mathrm{mg} / \mathrm{ml}$ in this result showed that the concentration still was not able to eliminate all the occurrence of contamination on Lopholejeunea sp. gametophyte explants. All explants were contaminated on the 21st day (Figure 3). However, exposure to "Bayclin" can reduce contamination until the $3^{\text {rd }}$ day after planting.

Bacteria and fungi were the contaminants that exist on Lopholejeunea sp. culture. Macroscopic and microscopic observations were made to prove the concordance between the type of contaminants with the given category. The red arrow in Figure 4, showed the contaminant that we observed based on macroscopic and microscopic morphology to confirm the type of contamination. The result showed based on macroscopic and microscopic observations, bluegreen fungi (Figure 4a), white-brown fungi (Figure 4b) confirm by microscopic structure which consist hyphae (Figure $4 \mathrm{~d}$ and e). Besides that, we found pink layer of bacteria (Figure $4 \mathrm{c}$ ) which consist of the bacteria cell under the microscope observation. All those contaminant growths on the surface of explant, so we assumed that this contaminant source was from the explant, and we categorized it for internal contamination. Meanwhile, we found black fungi located distribute on the medium not having contact with the explant, and we categorized it for external contamination (Figure 5).

Fungal and bacterial contamination which found in internal explants were thought to be carried from their original growth location. The contaminant did not remove entirely or damaging their cells when exposed to sterilization materials. Besides, the given concentration of "Bayclin" did not strong enough to kill the hidden spores in explants. Other possibility, 
Table 2. The explants color of Lopholejeunea sp. culture before and after exposure to disinfectant

\begin{tabular}{|c|c|c|c|c|c|c|c|}
\hline \multirow{3}{*}{ Treatment $(\mathrm{n}=10)$} & \multirow{3}{*}{$\begin{array}{l}\text { Color before } \\
\text { sterilization }\end{array}$} & \multicolumn{6}{|c|}{ Color after sterilization } \\
\hline & & \multicolumn{3}{|c|}{ After sterilization (D0) } & \multicolumn{3}{|c|}{ After 21 days (D21) } \\
\hline & & Ace paint code & Category & Color & Ace paint code & Category & Color \\
\hline $\mathrm{K}$ & & 75 & Pine bough & & & & \\
\hline AY & & 77 & Paradise hill & & & & \\
\hline $\mathrm{AZ}$ & 14 & 78 & Springside & & 28 & $\begin{array}{l}\text { Burnished } \\
\text { gold }\end{array}$ & \\
\hline BY & Honeysuckle & & & & & & \\
\hline BZ & vine & & & & & & \\
\hline $\mathrm{CY}$ & & 79 & Summerside & & & & \\
\hline
\end{tabular}

K: Tetracycline $2.5 \mathrm{mg} / \mathrm{ml}$ (1 minute), AY: Bayclin 0.5\% (60 seconds) + Tetracycline $2.5 \mathrm{mg} / \mathrm{ml}$ (1 minute), AZ: Bayclin $0.5 \%$ (90 seconds) + Tetracycline $2.5 \mathrm{mg} / \mathrm{ml}$ (1 minute), BY: Bayclin 0.75\% (60 seconds) + Tetracycline $2.5 \mathrm{mg} / \mathrm{ml}$ (1 minute), BZ: Bayclin 0.75\% (90 seconds) + Tetracycline $2.5 \mathrm{mg} / \mathrm{ml}$ (1 minute), CY: Bayclin 1\% (60 seconds) + Tetracycline $2.5 \mathrm{mg} /$ $\mathrm{ml}$ (1 minute), CZ: Bayclin 1\% (90 seconds) + Tetracycline $2.5 \mathrm{mg} / \mathrm{ml}$ (1 minute)

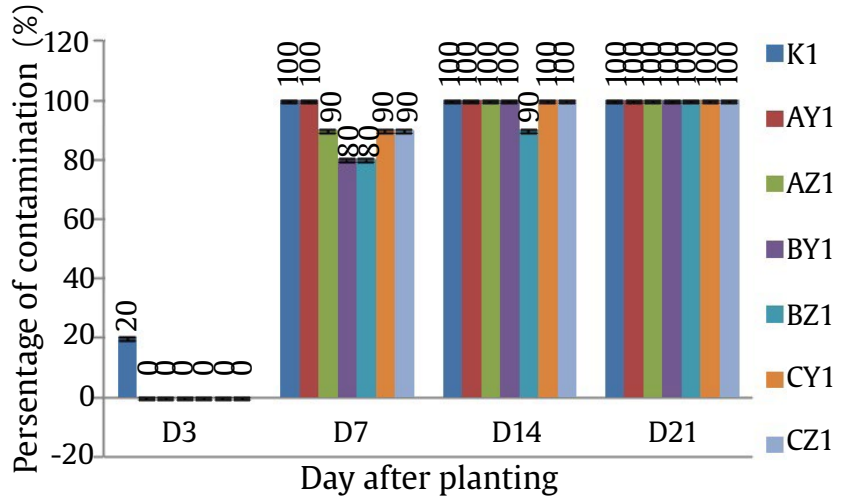

Figure 3. Percentage of culture contamination on Lopholejeunea sp. in vitro culture day 21 after planting. K: Tetracycline $2.5 \mathrm{mg} / \mathrm{ml}$ (1 minute), AY: Bayclin 0.5\% (60 seconds) + Tetracycline $2.5 \mathrm{mg} / \mathrm{ml}$ (1 minute), AZ: Bayclin 0.5\% (90 seconds) + Tetracycline $2.5 \mathrm{mg} / \mathrm{ml}$ (1 minute), BY: Bayclin 0.75\% (60 seconds) + Tetracycline $2.5 \mathrm{mg} / \mathrm{ml}$ (1 minute), BZ: Bayclin 0.75\% (90 seconds) + Tetracycline $2.5 \mathrm{mg} / \mathrm{ml}$ (1 minute), CY: Bayclin 1\% (60 seconds) + Tetracycline 2.5 $\mathrm{mg} / \mathrm{ml}$ (1 minute), CZ: Bayclin 1\% (90 seconds) + Tetracycline $2.5 \mathrm{mg} / \mathrm{ml}$ (1 minute)

that contamination occurs due to the presence of endophytic microorganisms. Those explain how the fungi and bacteria contamination tends to appear within a certain day's gap after planting, which is between first to fourth weeks.

\subsection{Explants Growth}

The growth of explants not yet observed on the $3^{\text {rd }}$ and $7^{\text {th }}$ day. There were no additional branches or increased in size from the explant. After the $14^{\text {th }}$ day, new branches began to appear and continued to grow. Then after $40^{\text {th }}$ days, explants that were initially yellow, turned to brown. Although the browning or aging occurred on the explants, the liverwort can still grow. Based on observations from the Lopholejeunea sp. gametophyte color in nature, the apical part tends to be bright green. Meanwhile, the base part showed brown color, which indicates that the explant color difference from the explant related to liverworts gametophyte aging. Also, if a browning reaction occurs, the color of the medium turned brown, and there no sign of the explant to growth and the explant tend to die.

Based on microscopic observations, the original explants were dark brown (Figure 6), while new branches appear from the base of the lobes (green) and have rhizoid in the ventral region. Branches that grow continued to elongate and straighten by time. The dark brown original explants tend to die after the buds coming and no oil bodies observed in the dead tissue.

Quantification of explant growth is presented based on the percentage of explant growth and the number of branches. Explant growth data by branch was obtained from counting the number of branches from 3 explants in each treatment bottle. The following is the percentage of explant growth and the number of branches in each treatment up to the $30^{\text {th }}$ day presented in Table 3 . Based on this table, Bayclin concentrations of $0.5 \%, 0.75 \%$, and $1.0 \%$ had relatively higher growth percentages than controls. It means the sterilization process and certain condition of contamination do not inhibit the explants growth. 

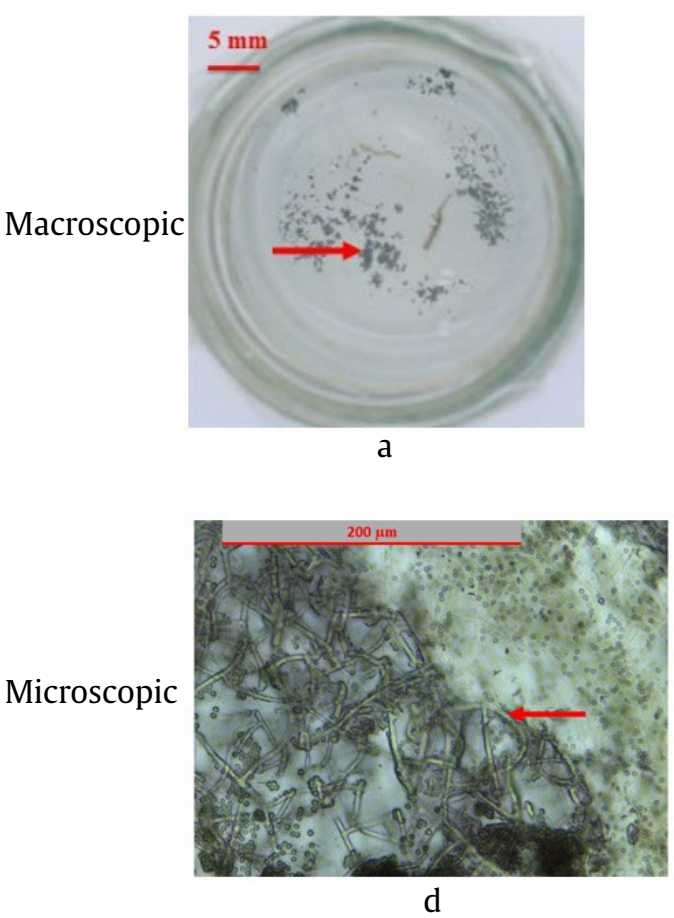

Type of contaminant

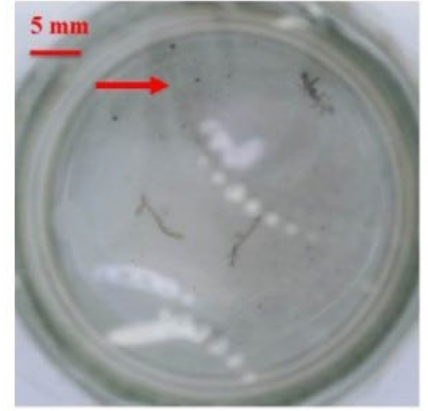

b

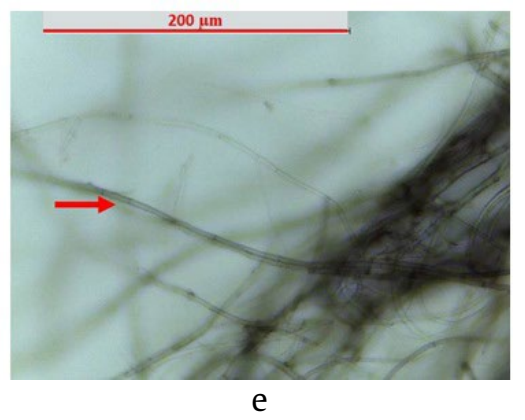

White-brown fungi

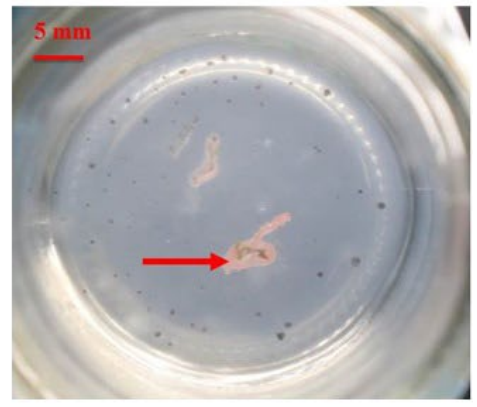

C

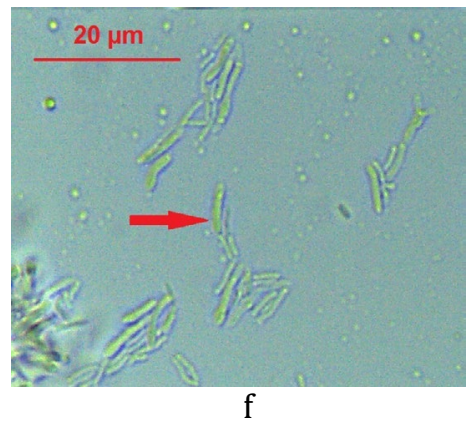

Pink bacteria

Figure 4. The variation of internal contaminants (red arrows) culture of Lopholejeunea sp. based on macroscopic and microscopic observation (a), blue-green fungi on macroscopic (b), white-brown fungi on macroscopic (c), pink bacteria on macroscopic (d), blue-green fungi on microscopic (e), white-brown fungi on microscopic (f), pink bacteria on microscopic

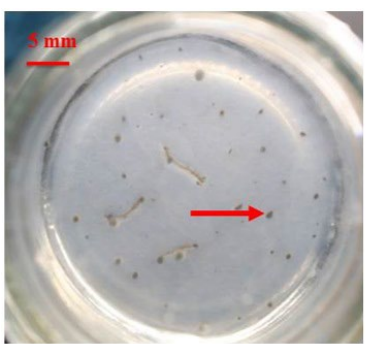

a

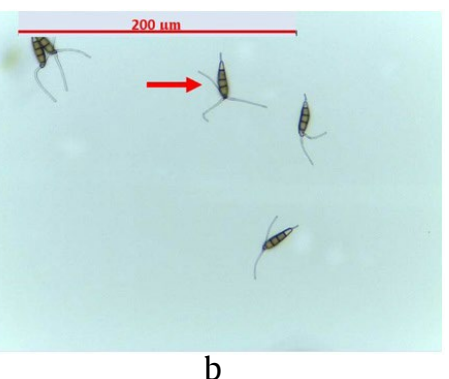

Figure 5. External contaminant (red arrows) of Lopholejeunea sp. culture (a) macroscopic observation, (b) microscopic observation

\section{Discussion}

The color of liverworts gametophyte explant changed after exposed to disinfectant. It assumed that the chlorophyll in cells degrades due to the addition of "Bayclin". Sodium hypochlorite is an antiseptic, clothing bleach, and cleaning fluid. Pandey et al. (2014) reported that moss gametophyte was very sensitive to sodium hypochlorite. Even exposure in a short time could damage the tissues because the

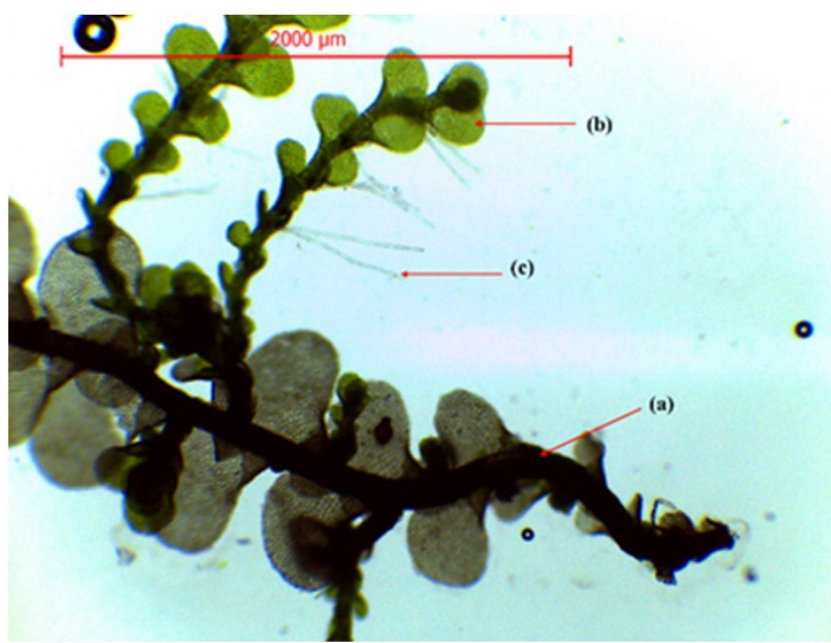

Figure 6. Microscopic observation results of growth of Lopholejeunea sp. (a) initial explants, (b) new branches that grow from the base of the lobes, (c) rhizoid

liverwort has only thin cuticles that unable to protect tissues from disinfectant exposure (Pandey et al. 2014). 
Table 3. Percentage of explant growth and number of branches Lopholejeunea sp. culture after 30 days planting

\begin{tabular}{lcc}
\hline Treatment & $\begin{array}{l}\text { Percentage of explants } \\
\text { growth }(\%)(\mathrm{n}=10)\end{array}$ & $\begin{array}{l}\text { Number of branches } \\
(\mathrm{n}=10)\end{array}$ \\
\hline K & $10 \pm 0.14$ & 9 \\
AY & $10 \pm 0.14$ & 2 \\
AZ & $50 \pm 0.42$ & 23 \\
BY & $90 \pm 0.14$ & 38 \\
BZ & $50 \pm 0.14$ & 20 \\
CY & $50 \pm 0.14$ & 15 \\
CZ & $60 \pm 0.0$ & 30 \\
\hline
\end{tabular}

K: Tetracycline $2.5 \mathrm{mg} / \mathrm{ml}$ (1 minute), AY: Bayclin 0.5\% (60 seconds) + Tetracycline $2.5 \mathrm{mg} / \mathrm{ml}$ (1 minute), AZ: Bayclin $0.5 \%$ (90 seconds) + Tetracycline $2.5 \mathrm{mg} / \mathrm{ml}$ (1 minute), BY: Bayclin $0.75 \%$ (60 seconds) + Tetracycline $2.5 \mathrm{mg} / \mathrm{ml}$ (1 minute), BZ: Bayclin 0.75\% (90 seconds) + Tetracycline $2.5 \mathrm{mg} / \mathrm{ml}$ (1 minute), CY: Bayclin 1\% (60 seconds) + Tetracycline $2.5 \mathrm{mg} / \mathrm{ml}$ (1 minute), CZ: Bayclin 1\% (90 seconds) + Tetracycline $2.5 \mathrm{mg} / \mathrm{ml}$ (1 minute)

The explants with from all of the treatments had burnished gold colors or dark brown on the $21^{\text {th }}$ day. The explants aging or browning assumed occurred on the explants. The explants aging expected to have the color change from green to brown and can develop new buds from the node area. Meanwhile, browning of moss explants indicates that cell death occurs due to cells not being able to convert phenolic acids into flavonoids (Krishnan et al. 2014).

The addition of disinfectants containing sodium hypochlorite for surface sterilization of explants commonly used in many related studies (Felek et al. 2015; Setiani et al. 2018; Sulistiyo et al. 2018; Zinabu et al. 2018). Sodium hypochlorite is known to have antibacterial activity by damaging bacterial cell walls. Chlorine ions trigger oxidative reactions followed by enzyme inactivation and lipid degradation (Estrella et al. 2002; Pais et al. 2016).

Vujicic et al. (2012) reported the addition of sodium hypochlorite to be successful in sterilizing the liverwort gemma with Marchantia polymorpha polymorpha up to $70 \%$. The percentage of sterile gametophyte culture is still low, despite using sodium hypochlorite concentrations of $0.825 \%$ (Carey et al. 2015). Following the statement of Farooq et al. (2002) the addition of sodium hypochlorite is not effective in killing contaminants at low concentrations. Also, Kritzinger et al. (1997) state that addition of sodium hypochlorite alone cannot eliminate the cause of contamination. However, the use of "Bayclin" for mosses sterilization still recommended if the concentration between $0.75 \%$ to $1.0 \%$ and the exposure time is 60 seconds to 90 seconds. Besides, it is necessary to add additional types of sterilizing materials after Bacylin's exposure to minimize further contamination.

The contamination location of Lopholejeunea sp. culture can be divided into two categories, such as internal and external, from the explant. The internal contamination site was the contaminant that appears near and touches the surface from the explant. External location is the contamination that appears does not reach explants or by the edge of the culture medium. According to Setiani et al. (2018), external contamination can come from environment, while internal contamination comes from contaminants that live inside the explants. Other ways to eliminate internal contamination is by giving fungicides and antibiotics into the medium (Kritzinger et al. 1997).

The black fungi contamination was located surrounding the explant (Figure 4). Based on comparing the results, we suspect black fungi contaminants were from the explants internal (endophytes), which appear after two weeks. It is known that liverworts have endophytic microorganisms namely Ascomycota and Basidiomycota phyla (Duckett et al. 2006; Ligrone et al. 2007; Davis and Shaw 2008). The similarity of the phylum gave rise to the suspicion that the fungi were one of the endophytic fungi of the liverwort Lopholejeunea sp. According to Duckett et al. (2006), hyphae can enter the moss tissue through the tip of the rhizoid and settle on the moss stem. The fungus and bacteria found appearing located internally and externally are thought to originate from explants.

The growth from the explant in this culture condition caused by two factors, there was the viability of explant after exposure to the disinfectants and the possible interaction between the liverwort and microorganisms. The explant bleaching after sterilization indicates the explant's death. Moreover, if the explants turned brown, the color of the medium also turned brown, and no sign of growth (Singh 2018), then the explants will die. However, for the browning explant in this study, the cultures still can be maintained even though the explant color turned to brown by time. The explants still have a chance to grow because of the chloroplasts still functioning to support the explant growth and development (Jensen and Leister 2014). Zhu and Gradstein (2005) state that when the environmental conditions are humid and shaded, the moss will stretch its attachment and grow vertically. 
Even though the explants have been contaminated, they can still grow (Table 3 ). This growth can happen related to the natural habitat of liverwort that coexists with various types of microorganisms (Makinde et al. 2014) and the contamination did not that severe to cause damage to the explant cells. Based on Davey and Currah (2006), there is a possibility of interaction between mosses and fungi. Meanwhile, according to Chopra and Kumra (1988), some species of mosses cannot grow if they are not symbiotic with fungi and bacteria. However, further research is needed to determine the relationship between the growth of mosses and the symbiosis even in culture condition and to the identification and to study the interaction between them.

\section{Conclusion}

The results showed that the "Bayclin" concentration at $0.75 \%$ with exposure time of 60 and 90 seconds have the lowest level of contamination until the $7^{\text {th }}$ day. The most common type of contamination was bacteria and fungi that arise from the explant part (internal). The presence of contamination and browning do not inhibit the growth of explants, except when it contaminated with the blue-green fungi. Varieties of fungicides and antibiotics should be tested in the culture medium of liverworts Lopholejeunea sp. Based on this result, in the future we need to optimize the sterilization method to suppress the explant contamination and to get axenic culture of liverworts Lopholejeunea sp. From this result, adjusting the type of fungicides and antibiotics with the most potent concentration and exposure time should be tested to obtain an axenic and viable culture of liverworts Lopholejeunea sp.

\section{Acknowledgements}

We are grateful to the Ministry of Research, Technology, and Higher Education of the Republic of Indonesia for supporting this work through research grants Hibah Penelitian Dasar Perguruan Tinggi (PDUPT) Grant No. NKB-197/UN2.RST/ HKP.05.00/2020.

\section{References}

Abdullah MT et al. 2019. Greater Kenyir Landscapes: Social Development and Environmental Sustainability from Ridge to Reef. Cham: Springer Nature Switzerland.
Allsopp A. 1957. Controlled differentiation in cultures of two liverworts. Nature 179:681-682. DOI:10.1038/179681a0

Asakawa Y. 2012. Liverworts-potential source of medicinal compounds. Medicinal Aromatic Plants 1:1-3. DOI:10.2174/138161208786404272

Bahuguna YM et al. 2013. Bryophytes and ecosystem. Biodiversity of Lower Plants 2013:279-296.

Beike AK et al. 2010. Axenic bryophyte in vitro cultivation. Journal of Endocytobiosis and Cell Research 20:102-108.

Carey SH et al. 2015. A method for eliminating bacterial contamination from in vitro moss cultures. Applications in Plant Sciences 3:1-5. DOI:10.3732/apps.1400086

Chopra RN, Kumra PK. 1988. Biology of Bryophytes. New Delhi: Wiley Eastern Limited.

Crandall-stotler B et al. 2008. Morphology and Classification of The Marchantiophyta. In: Goffinet B and Shaw AJ. 2008. Bryophyte Biology: Second Edition. United Kingdom: Cambridge University Press.

Davey ML, Currah RS. 2006. Interactions between mosses (Bryophyta) and fungi. Canada Journal Botany 84:1509-1519. DOI:10.1139/b06-120

Davis EC, Shaw AJ. 2008. Biogeographic and phylogenetic patterns in diversity of liverwort-associated endophytes. American Journal of Botany 95:914-924. DOI:10.3732/ajb.2006463

Duckett JG et al. 2004. In vitro cultivation of bryophytes: a review of practicalities, problems, progress and promise. Journal of Bryology 26:3-20. DOI: $10.1179 / 037366803235001742$

Duckett JG et al. 2006. Basidiomycetous endophytes in jungermannialean (leafy) liverworts have novel cytology and species specific host ranges: a cytological and experimental study. Canadian Journal of Botany 84:1075-1093. DOI:10.1139/b06-073

Estrella C et al. 2002. Mechanism of action of sodium hypochlorite. Brazilian Dental Journal 13:113-117. DOI:10.1590/S0103-64402002000200007

Farooq SA et al. 2002. Micropropagation of Annona squamosa L. using nodal explants. Pakistan Journal of Biological Sciences 5:43-46. DOI:10.3923/pjbs.2002.43.46

Felek W et al. 2015. Optimization of explants surface sterilization condition for field grown peach (Prunus persica L. Batsch. Cv. Garnem) intended for in vitro culture. African Journal of Biotechnology 14:657-660. DOI:10.5897/AJB2014.14266

Glime JM. 2017. Bryophyte Ecology: Marchantiophyta Vol 1. USA: Michigan Technological University and the International Association of Bryologists.

Gradstein SR et al. 1988. On the taxonomic significance of secondary metabolites in the Lejeuneaceae (Hepaticae).Journal Haltori Botany Laboratory 64:159168.

He X et al. 2013. The oil bodies of liverworts: unique and important organelles in land plants. Critical Reviews in Plant Sciences 32:293-302. DOI:10.1080/0735268 9.2013.765765

[ITIS] Interagency Taxonomic Information System. 2008. Lopholejeunea. Available at: https://www. itis.gov/servlet/SingleRpt/SingleRpt? search topic=TSN\&search_value=15248\#null: [Date accessed: 17 March 2019]

Jensen PE, Leister E. 2014. Chloroplast evolution, structure and functions. 1000FPrime Reports 6:1-40. DOI:10.12703/ P6-40

Konrat M et al. 2008. Early Land Plants Today: Global Patterns of Liverwort Diversity, Distribution, and Floristic Knowledge. In: Mohamed H, Haky BB, NasrulhaqBoyce A. 2008. Bryology in the New Millennium. Kuala Lumpur: University of Malaya. 
Krishnan $\mathrm{R}$ et al. 2014. Establishment of cell suspension culture in Marchantia polymorpha linearis Lehm and Lindenb. for the optimum production of flavonoids. Biotech 4:49-56. DOI:10.1007/s13205-013-0123-7

Kritzinger EM et al. 1997. Elimination of external and internalcontaminants in rhizomes of Zantedeschia aethiopicawith commercial fungicides and antibiotics. In: Cassel AC (Eds.). Pathogen and microbial contamination management in micropropagation. Dordrecht: Springer Science Business Media. pp. 161-167.

LaRoe ET. 1995. Our Living Resources: A Report to The Nation on The Distribution, Abundance, and Health of U.S Plants, Animals, and Ecosystems. Washington DC: National Academic Service,

Ligrone R et al. 2007. Glomeromycotean associations in liverworts: a molecular, cellular, and taxonomic analysis. American Journal of Botany 94:1756-1777. DOI:10.3732/ajb.94.11.1756

Makinde AM et al. 2014. Studies of sterilization protocol development and calli induction of selected tropical mosses. Journal of Tropical Biology and Conservation 11:33-40.

Pais AK et al. 2016. Sodium hypochlorite sterilization of culture medium in micropropagation of Gerbera hybrida cv. Essandre. African Journal of Biotechnology 15:1995-1998. DOI:10.5897/AJB2016.15405

Pandey VKet al. 2014. In vitro culture of moss Bryum coronatum schwaegr.(bryaceae) and it's phytochemical analysis. International Journal of Pharmacy and Pharmaceutical Sciences 6:307-311.

Sabovljevic A et al. 2009. Isolation in bryophytes. In: Jain SM and Praveen S. 2009. Protocols for in vitro cultures and secondary metabolite analysis of aromatic and medicinal plants. Methods in Molecular Biology. New Delhi: Humana Press.

Sabovljevic M et al. 2014. Bryophyte conservation biology: In vitro approach to the ex situ conservation of bryophytes from Europe. Plant Biosystems 148: 1-12. DOI:10.1080/11263504.2014.949328
Setiani NA et al. 2018. Pengaruh desinfektan dan lama perendaman pada sterilisasi eksplan daun sukun (Artocarpus altilis (Parkinson ex. F.A Zorn) Fosberg). Biotropika: Journal of Tropical Biology 6:78-82. DOI:10.21776/ub.biotropika.2018.006.03.01

Silva-e-Costa JD et al. 2016. Spore germination, early development and some notes on the effects of in vitro culture medium on Frullania ericoides (Nees) Mont. (Frullaniaceae, Marchantiophyta). Acta Botanica Brasilica 31:19-28. DOI:10.1590/0102$33062016 a b b 0336$

Singh CR. 2018. Review on problems and its remedy in plant tissue culture. Asian Journal of Biological Sciences 11:165-172. DOI:10.3923/ajbs.2018.165.172

Sulistiyo RH et al. 2018. Pengaruh teknik sterilisasi dan komposisi medium terhadap pertumbuhan tunas eksplan sirsak ratu. Bioedukasi: Jurnal Pendidikan Biologi 11:1-5.

Tuba Z et al. 2011. Bryophyte Ecology and Climate Change. Cambridge: Cambridge University Press.

Vujicic M et al. 2012. In vitro development of the rare and endangered moss Molendoa hornschuchiana (Hook.) Lindb. Ex Limpr. (Pottiaceae, Bryophyta). HortScience 47:84-87.

Vujičić M et al. 2010. Axenically culturing the bryophytes: a case study of the liverwort Marchantia polymorpha 1. Ssp. Ruderalis bischl. and boisselier(Marchantiophyta, Marchantiaceae). Kragujevac Journal Science 32:73-81.

Zhu R, Gradstein SR. 2005. Monograph of Lopholejeunea (Lejeuneaceae, Hepaticae) in Asia. Systematic Botany Monographs 74:1-98. DOI:10.2307/25027938

Zinabu D et al. 2018. Explants sterilization protocol for in vitro propagation of elite enset (Ensete ventricosum (Welw.) Chessman) Cultivars. Asian Journal of Plant Science and Research 8:1-7. 